\title{
PROFESSOR OWEN MARTIN PHILLIPS 30 December 1930-12 October 2010
}

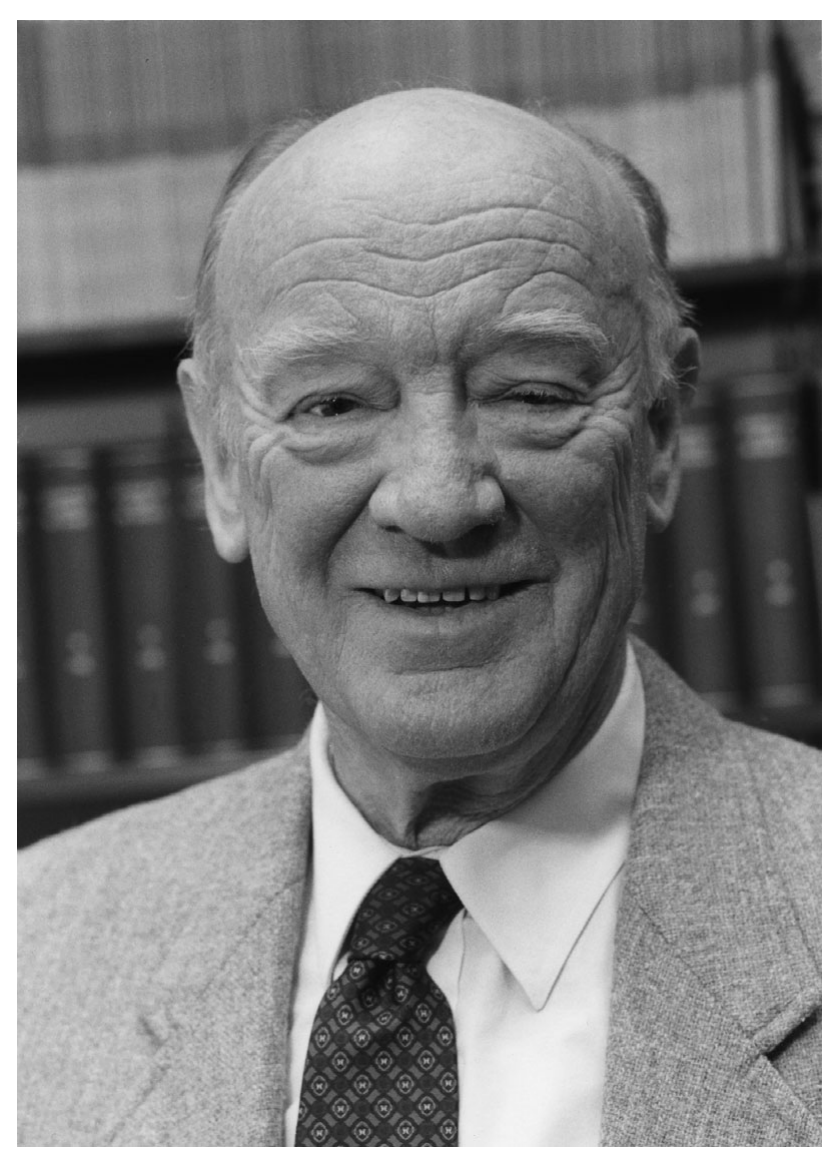

Owen Phillips grew up in Sydney, Australia, and following a distinguished record at a State high school and in the final NSW school examinations, he enrolled in the Faculty of Engineering at the University of Sydney in 1948. In the third year, he transferred to the Faculty of Science to do more advanced courses in Mathematics and Physics (with the idea of going back to Engineering after one year and qualifying for a Science degree on the way). Owen did so well, however, that he went on to do a fourth year in Mathematics and graduated with First Class Honours.

He then won a Scholarship to Cambridge, where he enrolled in Trinity College and did his PhD under George Batchelor's supervision. Before leaving Sydney, he had married Merle Simons, and their first daughter Lynette was born while they were living in Cambridge. They subsequently had two sons, Michael and Chris, and a second daughter Bronwyn.

In 1957, Owen was elected to a Research Fellowship at St John's College, Cambridge, and soon after that he spent his first period at Johns Hopkins University. Between 1961 and 1964, he was an Assistant Director of Research in Cambridge; during this time, he produced a manuscript continuing the theme of his $\mathrm{PhD}$, 
which was awarded the Adams Prize for the years 1963-1964 by the University of Cambridge. This draft became the influential monograph 'Dynamics of the Upper Ocean', published by Cambridge University Press (CUP) in 1966, which ran to a third edition in 1976, and was translated into Russian and Chinese. Owen became an Assistant Editor of the Journal of Fluid Mechanics in 1961 and was elevated to the rank of Associate Editor in 1965, remaining so until 1995. Other than the Founding Editor, George Batchelor himself, Owen has thus been the longest serving member of the Editorial Board of the Journal.

After this second period in Cambridge, Owen returned to Johns Hopkins as a full Professor, first of Geophysical Mechanics and then of Geophysics. The whole of his subsequent career was spent at that University; he became Decker Professor of Science and Engineering in 1975, and in 1998 he retired as an Emeritus Professor. There was a memorable conference held in Owen's honour at Johns Hopkins in 1998, celebrating his 40 years there. Family, colleagues, students and friends spoke warmly of his many achievements and the various interactions with him that we had all valued.

Owen received so many honours and awards during his career that only the most notable can be mentioned here. He was elected to the Royal Society in 1968 at an unusually early age. He was awarded the Sverdrup Gold Medal of the American Meteorological Society in 1975, and became a Member of the US National Academy of Engineering in 1996. In 1997, he was elected an Honorary Fellow of Trinity College, Cambridge. He served on many influential committees both at Johns Hopkins and other institutions and public bodies in Maryland and around the USA.

Owen had the gift of writing extremely clearly on a variety of topics. As well as his many journal papers, he was moved to publish significant books outside his major specialty: 'The Heart of the Earth', 1968; 'The last Chance Energy Book', 1979; 'Wave Dynamics and Radio Probing of the Ocean Surface', 1985 and 'Flow and Reactions in Permeable Rocks', 1990. An updated and expanded version of this last book was published by CUP in 2009 under the title 'Geological Fluid Dynamics'.

I will end on a more personal note, by recalling briefly significant stages in my friendship with Owen over more than 60 years. We first met when we enrolled as undergraduates at Sydney University on the same day, and became practical physics partners for three years. We overlapped again as $\mathrm{PhD}$ students in Cambridge, where I joined the fluid dynamics group two years after Owen. Although we eventually made our careers on opposite sides of the world we always kept in touch, and met in many different places. Especially memorable were the periods when we were spending summers at the same time on Cape Cod, where the Phillips family have a holiday house at Quissett.

Stewart Turner, Research School of Earth Sciences, Australian National University 